\title{
Morphometric Analysis to Infer Hydrological Behaviour of Lidder Watershed, Western Himalaya, India
}

\author{
Farrukh Altaf, Gowhar Meraj, and Shakil A. Romshoo \\ Department of Earth Sciences, University of Kashmir, Hazratbal, Srinagar, Kashmir 190006, India \\ Correspondence should be addressed to Gowhar Meraj; gowharmeraj@gmail.com
}

Received 17 January 2013; Revised 1 March 2013; Accepted 3 March 2013

Academic Editor: Biswajeet Pradhan

Copyright ( 2013 Farrukh Altaf et al. This is an open access article distributed under the Creative Commons Attribution License, which permits unrestricted use, distribution, and reproduction in any medium, provided the original work is properly cited.

\begin{abstract}
West Lidder River, in the Northwest Greater-Himalayan mountain range, is the major source of irrigation and drinking water supplies for the Kashmir Valley with a population of seven million people. The major source of water for the whole Lidder River is snow and icemelt emanating from its two subcatchments East Lidder and West Lidder. Snowmelt significantly contributes to the evolution of drainage patterns in this area. Quantitative morphometry plays a vital role in routing the snowmelt and other hydrological processes. Morphometric analysis of the West Lidder River catchment was carried out using geospatial technique. The outcome revealed that the entire study area has uniform lithology and is structurally permeable. The high drainage density of all subwatersheds indicate more surface runoff. The morphometric analysis also indicates that the area is more prone to weathering due to very-coarse to coarse drainage texture. All the subwatersheds showed dendritic to subdendritic drainage pattern. An immense control of structure on the drainage in some subwatersheds is indicated by their high bifurcation ratios. Circulatory and elongation ratios show that the subwatersheds have elongated to circular shapes. From the integrated analysis of the morphometric parameters, important hydrologic behaviour of 17 subwatersheds could be inferred.
\end{abstract}

\section{Introduction}

The measurement and mathematical analysis of the configuration of the earth's surface, shape, and dimension of its landforms is called morphometry [1-3]. To understand the evolution and behaviour of drainage patterns, several quantitative methods have been developed $[4,5]$. In hydrology, basin drainage characteristics are fundamental in understanding various hydrological processes. Since watershed is the basic unit in hydrology; therefore, morphometric analysis at watershed scale is advantageous and preferable rather carry it out on individual channel or inconsistent segment areas. Watershed is an area of surface whose major runoff is conveyed to the single outlet and is the appropriate unit to study several processes of the land surface. For example, watershed is considered a fundamental erosional landscape element, wherein conspicuous interaction of land and water resources takes place. Being fundamental units of fluvial terrain, considerable research focal point has been done on watershed geometric characterization such as stream network topology and quantitative narration of shape, pattern, and drainage texture [5]. Hydrologic and geomorphic processes occur within the watershed, and morphometric characterization at the watershed scale reveals information regarding formation and development of land surface processes $[6,7]$ and thus provides a holistic insight into the hydrologic behaviour of a watershed. Basin travel time, time to hydrograph peak (basin lag time), and intensity of erosional processes operating at watershed scale can be predicted with better insight and accuracy from morphometric evaluation of a watershed. For unguaged watersheds wherein, in addition to hydrology, information regarding soil, geology, geomorphology, and so forth is also scarce, morphometric analysis provides a very good alternative to understand the underlying factors controlling the hydrological behaviour [8]. Furthermore, there are a myriad of practical applications of quantitative morphometric analysis such as river basin evaluation, watershed prioritization for soil and water conservation, and management of natural resources. Watershed morphometric analysis dispenses a quantitative description of the drainage system and thus enabling a better characterization of watersheds [9]. The role of landform processes, soil physical properties, 
and erosional characteristics in shaping the idiosyncrasy of different watersheds can be best evaluated through juxtaposing their morphometric parameters [7]. Using conventional techniques, morphometric characterization of many river basins and subbasins in different parts of the globe has been carried out [9-11]. With the advancement in geospatial and computer technology, assessment of the drainage basin morphometry has been more accurate and precise. Nowadays, using Geographical Information System (GIS) technique, various terrain and morphometric parameters of the drainage basins are evaluated with more ease and better accuracy. Satellite data and GIS tools have been successfully employed to generate data on the spatial deviations in drainage characteristics thus providing an insight into hydrologic conditions necessary for developing watershed management strategies [12-14]. GIS, being a powerful tool for the manipulation and analysis of spatial information, provides a flexible environment for morphometric analysis. In the present study, morphometric characterization of 17 subwatersheds of the West Lidder River catchment was performed in GIS environment. The importance of morphometric analysis for this region lies in the fact that Lidder River forms the back bone of irrigation, drinking water supplies, and economy of the Kashmir valley. Snowmelt runoff contributes significantly to the drainage evolution of the area. Comparison of the quantitative morphometric parameters of subwatersheds of a river helps in understanding the geomorphological effects on the spatiotemporal variation of the hydrological functions. Moreover, some of the morphometric parameters such as circularity ratio and bifurcation ratio are input parameters in the hydrograph analysis [15-18] and evaluation of surface water potential of an area [19]. In this context, this work represents a better understanding of hydrologic behaviour of the study area and its impact on various socioeconomic aspects of the valley of Kashmir. Moreover, a more rational approach of drainage morphometric analysis has been employed in this study compared to other automatically DEM-based drainage generation methods [20, 21]. It uses natural stream network and lake information to condition the DEM prior to the calculation of flow direction and flow accumulation grids. This greatly reduces error introduction in the form of spurious drainage.

\section{Materials and Methods}

\subsection{Materials}

2.1.1. Study Area. The West Lidder catchment occupies the Southeastern part of the Kashmir valley and is situated between $34^{\circ} 09^{\prime} 01^{\prime \prime} \mathrm{N}-34^{\circ} 14^{\prime} 00^{\prime \prime} \mathrm{N}$ and $75^{\circ} 06^{\prime} 00^{\prime \prime} \mathrm{E}-$ $75^{\circ} 23^{\prime} 29^{\prime \prime} \mathrm{E}$ (Figure 1). Forming a part of the middle Himalayas and lying between the Pir Panjal range in the South and Southeast, the north Kashmir range in the Northeast, and Zanskar range in the Southwest, the study area has a unique geoenvironmental setting making it a suitable niche to many of the important glaciers such as Kolahoi. The West Lidder catchment has been engraved out by West Lidder River, a left bank tributary of River Lidder which finally drains as a right bank tributary of River Jhelum. It has a catchment area of $350.6 \mathrm{~km}^{2}$, which constitute about 27.80 per cent of the total catchment area of river Lidder $[29,30]$. The valley begins from the base of the snow field called the Kolahoi giving rise to West Lidder catchment. The latter joins the East Lidder which originate from another snow field called Sheshnag near the famous tourist town of Pahalgam. From this point onwards, it is referred as River Lidder. The latter joins the Jhelum (upper stream of Indus River) at Gur Village after travelling a course of $70 \mathrm{~km}$ [30]. Combined action of glaciers and rivers has bestowed West Lidder catchment a marked topography. The valley possesses distinctive climatic characteristics because of its high altitude location and its geophysical setting, being enclosed on all sides by high mountain ranges. The study area receives precipitation in the form of both rain and snow. The mean annual precipitation at Pahalgam rain gauge station is $1267.2 \mathrm{~mm}$. The highest rainfall of $1629 \mathrm{~mm}$ was recorded during the year 1994 and the lowest of $899.9 \mathrm{~mm}$ during the year 2000. The area receives the highest rainfall in the month of March $(208.8 \mathrm{~mm})$ and the lowest in the month of October $(45.9 \mathrm{~mm})$. Such a climatic regime is peculiar characteristic of sub-Mediterranean type of climate. Moreover, 70 per cent of its annual precipitation concentrated in winter and spring months [31].

2.1.2. Data Sets Used. The data sets used in this study for accomplishing the respective objectives are as follows.

(i) Quantitative morphometry: ASTER DEM $30 \mathrm{~m}$.

(ii) Survey of India (SOI) topographical maps at 1:50,000; Dated: 1969: Natural drainage delineation.

\subsection{Methods}

2.2.1. Drainage Generation. Drainage was generated from Advanced Space borne Thermal Emission and Reflection Radiometer (ASTER) $30 \mathrm{~m}$ digital elevation model (DEM) in GIS environment. The Arc Hydro approach was used for drainage generation which is more logical and consistent when compared to a manual approach [32]. There is no distinction between water filled stream channels and land surface in a DEM. In order to incorporate already existing streams and lakes into the DEM for drainage analysis, a process termed as DEM manipulation is followed. Natural drainage present in SOI toposheets was digitized and used to manipulate the DEM. For proper determination of flow direction and flow accumulation, DEM sinks were identified and filled. Boundaries of the 17 subwatersheds were derived by defining pour point for each subwatershed (Figure 1). The pour point is the location where water drained from whole of the watershed flows into the main river. Based on the cumulative number of the upstream cells draining to each cell, stream network in both the watersheds was defined. We used a critical threshold 0.06 which represents the $6 \%$ area in all 17 subwatersheds for defining streams. The critical threshold is the minimum upstream drainage required to initiate a stream. Area of the watershed was evaluated by 


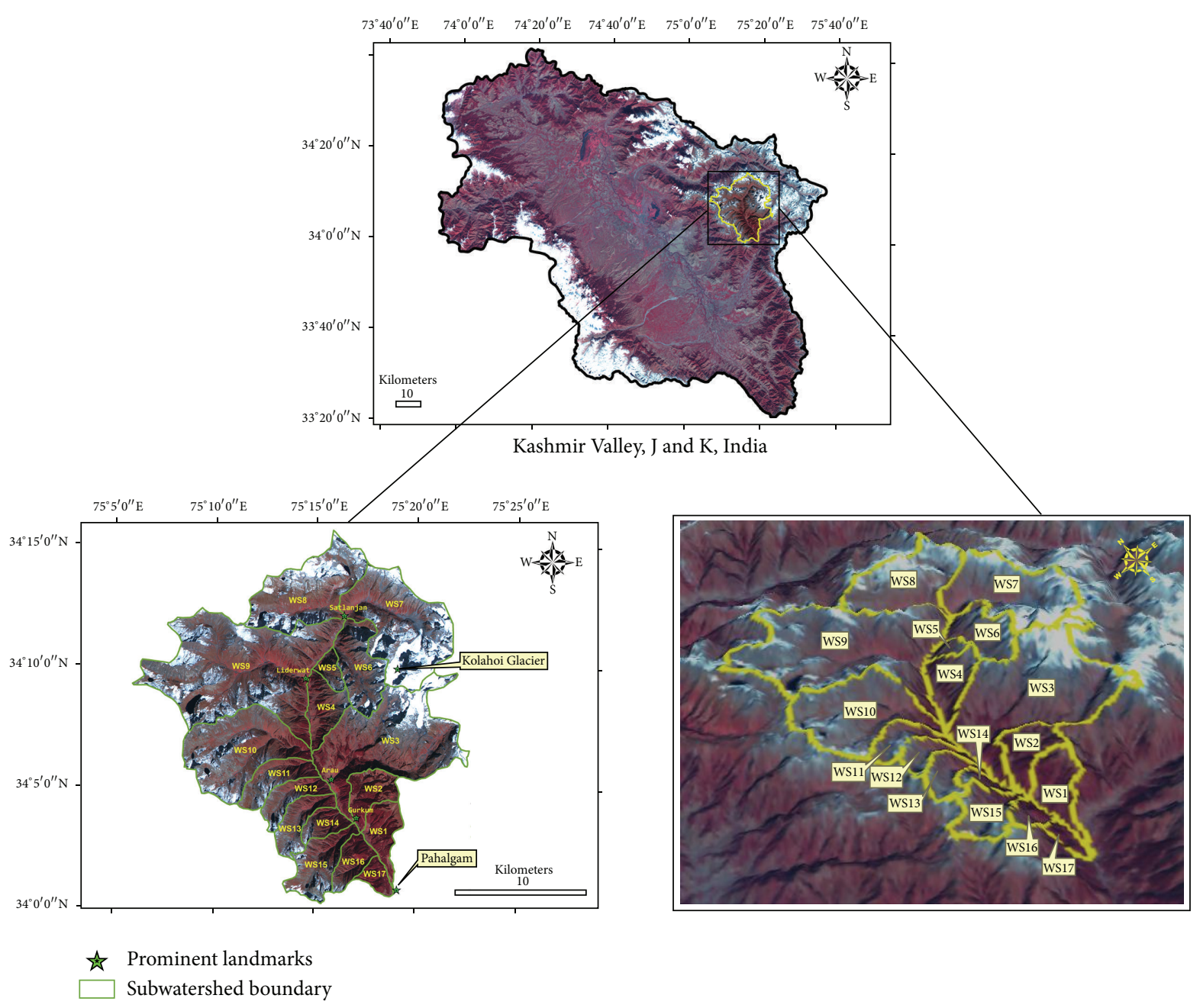

FIGURE 1: Showing location of the study area in 2D and 3D perspectives.

calculating the geometry of the derived watershed polygons, and length of the watershed was calculated by summing the length of the main stream channel and the distance from the top of the main channel to the watershed boundary. By summing the lengths of all stream segments in each subwatershed the total stream length was calculated.

2.2.2. Quantitative Morphometry. In the present study, morphometric analysis of the parameters, namely, stream order, stream length, bifurcation ratio, relief ratio, drainage density, drainage intensity, drainage texture, stream frequency, drainage texture, form factor, length of overland flow, constant channel maintenance, circulatory and elongation ratio, area, perimeter, and length of all the 17 subwatersheds have been carried out using the standard mathematical formulae given in the Table $1[9,10,19,22-28]$. The values of various basin characteristics required for calculating morphometric parameters are shown in Table 2.

\section{Results and Discussion}

3.1. Stream $\operatorname{Order}(U)$. The highest stream order among the 17 subwatersheds is five and is shown by four subwatersheds: WS7, WS8, WS9 and WS10. The lowest stream order is two and is shown by WS17. A perusal of Table 3 and Figure 1 indicates that the 17 subwatersheds draining into West Lidder River are contributing surface runoff and sediment loads differentially due to variations in their physical characteristics. There are only 7 subwatersheds in the East side of the river among which five watersheds have $U=4$ and only two watersheds have $U=5$. In the West side of the river, there are 10 watersheds out of which four watersheds have $U=3$, two watersheds have $U=4$, three watersheds have $U=5$, and only one watershed has $U=2$. Drainage maps of all the 17 subwatersheds are shown below (Figures 4(a), 4(b), and 4(c)). Higher stream order is associated with greater discharge, and higher velocity [33]. West side of the river clearly contributes more to discharge and since higher 
velocity enhances the erosion rates, therefore, this side also contributes higher sediment loads into the West Lidder River. Further, the total number of stream segments decrease with stream order. This is referred to as Horton's law of stream numbers. Any deviation indicates that the terrain is typified with high relief and/or moderately steep slopes, underlain by varying lithology and probable uplift across the basin [34]. In practice, when logarithms of the number of streams of a given order, are plotted against the order, the points lie on a straight line [22]. Similar geometric relationship was also found to operate between stream order and stream numbers in all subwatersheds of this study area. It indicates that the whole area has uniform underlying lithology, and geologically, there has been no probable uplift in the basin (Figure 2).

3.2. Stream Length (Lu)/Mean Stream Length (Lsm). Analysis of the results shown in Tables 3 and 4 show that the total length of stream segments is the maximum in case of first order streams. It decreases as order increases in all the subwatersheds (Tables 3 and 4; Figure 4). The results reaffirm the fact that the area is underlain with uniform lithology with no probable basin upliftment. The observation demonstrates that the area depends only on the drainage characteristics for movement of water. Further, since there are more number of watersheds in the West side of the river and the total stream length of all the orders from this side is greater than the East side, therefore, the longer travel times [35] makes this side hydrologically very active. From this observation, it is concluded that during a same intensity storm event over whole of the East or West side of the river [36], the East side will show short basin lag times [37] compared to West side under similar soil moisture [38,39] and vegetation cover [39]. Moreover, Table 4 indicates that $L s m$ in these subwatersheds range from a minimum of $0.21 \mathrm{~km}$ for stream order 2 of WS5 to a maximum of $6.69 \mathrm{~km}$ for the order 3 of WS13. According to the Horton's law of stream lengths, Lsm of any given order is greater than that of lower order. This geometric relationship can be seen in Figure 3. A comparative analysis of Lsm and stream length ratio $R L$ of all the subwatersheds is shown in Table 4 .

3.3. Stream Frequency/Channel Frequency (Fs). Stream frequency $(F s)$ is the total number of streams of all orders per unit area. The analysis of the results shown in Table 5 shows that Fs is maximum in subwatershed WS12 $\left(8.19 / \mathrm{km}^{2}\right)$, followed by WS8 $\left(7.98 / \mathrm{km}^{2}\right)$, WS9 $\left(7.82 / \mathrm{km}^{2}\right)$, WS13 $\left(7.05 / \mathrm{km}^{2}\right)$, WS7 $\left(7.04 / \mathrm{km}^{2}\right)$, WS5 $\left(7.02 / \mathrm{km}^{2}\right)$, WS10 $\left(6.70 / \mathrm{km}^{2}\right)$, WS6 $\left(6.52 / \mathrm{km}^{2}\right)$, WS16 $\left(6.15 / \mathrm{km}^{2}\right)$, WS1 $\left(5.93 / \mathrm{km}^{2}\right)$, WS4 $(5.78 /$ $\left.\mathrm{km}^{2}\right)$, WS15 $\left(5.64 / \mathrm{km}^{2}\right)$, WS3 $\left(5.63 / \mathrm{km}^{2}\right)$, WS2 $\left(5.15 / \mathrm{km}^{2}\right)$, WS11 $\left(4.52 / \mathrm{km}^{2}\right)$, WS14 $\left(4.12 / \mathrm{km}^{2}\right)$ and WS17 $\left(3.47 / \mathrm{km}^{2}\right) . F s$ has been related to permeability, infiltration capacity, and relief of watersheds $[40,41]$. The values observed in West Lidder indicate that W12 is having rocky terrain and very low infiltration capacity out of all the 17 subwatersheds. Further, it is noted that $F s$ decreases as the stream number increases. Fs of WS17 reveals that this subwatershed is comparably covered with good amount of vegetation and has very good infiltration capacity. Overall, the results of Fs reflect early

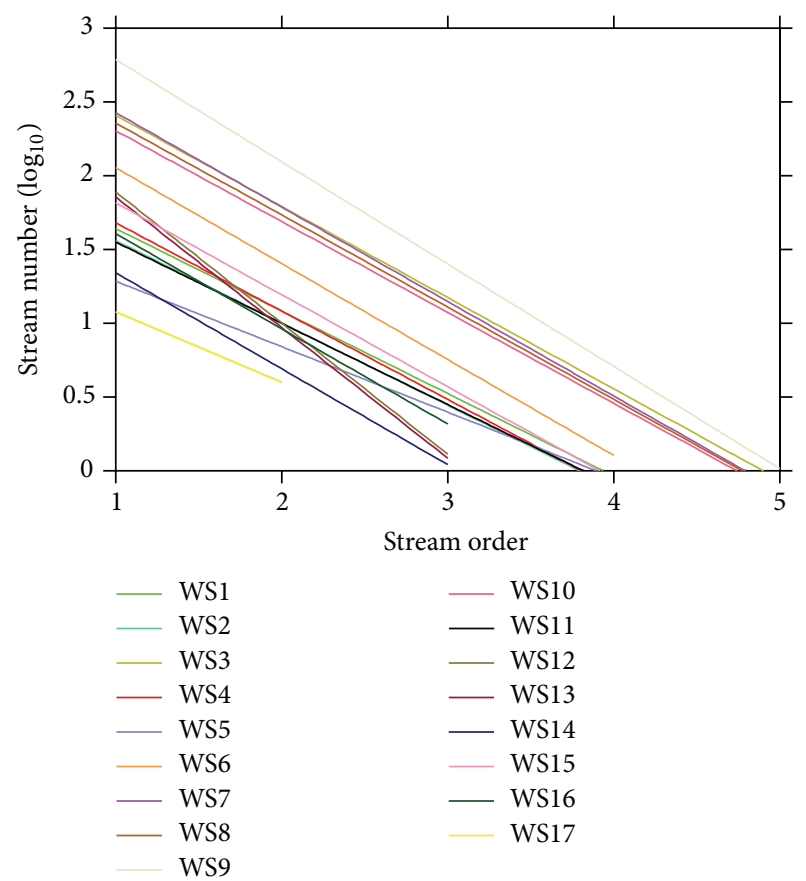

FIGURE 2: Showing relation between stream order and number of streams for 17 subwatersheds.

peak discharge for subwatersheds in order of their decreasing Fs resulting in flash floods, while the discharge from WS17 takes longer time to peak because of low runoff rates due to lesser number of streams [42-44].

3.4. Bifurcation Ratio (Rb)/Mean Bifurcation Ratio (Rbm). Analysis of the results shown in Table 5 shows that mean bifurcation ratio $(\mathrm{Rbm})$ of the 17 subwatersheds is 3.6, 3.7, 4, 4.1, 2.7, 4.8, 4.7, 4.5, 6.4, 5.3, 3.6, 10.2, 9.1, 4.6, 4.2, 4.4, and 3.0, for WS1 to WS17, respectively. Rbm does not precisely remain constant from one order to the next, because of possibility of variations in watershed geometry and lithology, but it tends to be a constant throughout the series. High Rbm indicates early hydrograph peak with a potential for flash flooding during the storm events $[45,46]$. Moreover, wherever in a basin, powerful geological control dominates; $R b m$ shows only a small variation for different regions on different environment [10]. Higher Rbm values are the characteristics of structurally more disturbed watersheds with a prominent distortion in drainage pattern and vice versa [14]. Maximum $R b m$ is seen for WS12 $(R b m=10.2)$, and thus it will show early hydrograph peak (smaller basin lag time) which also indicates strong structural control on the drainage development for this watershed. The minimum $\mathrm{Rbm}$ is observed for WS5 $(R b m=2.79)$, indicating delayed hydrograph peak.

3.5. Relief Ratio (Rh). Quantitatively, it is the measurement of the overall steepness of a drainage basin. Also, it is an indicator of the intensity of erosion processes operating on the basin slopes [47]. Rh normally increases with decreasing drainage area and size of a given drainage basin [48]. In 
TABLE 1: Methodology adopted for computation of morphometric parameters.

\begin{tabular}{|c|c|c|c|}
\hline S. No. & Morphometric parameters & Formulae & Reference \\
\hline 1 & Stream Order $(U)$ & Hierarchical rank (Strahler Scheme) & {$[9]$} \\
\hline 2 & Stream Length $(L u)$ & Length of the stream & {$[22]$} \\
\hline 3 & Mean Stream Length $(\mathrm{Lsm})$ & $\begin{array}{l}L s m=L u / N u ; \text { Where, } L s m=\text { mean stream length; } L u=\text { Total stream length of } \\
\text { order " } u \text { "; } N u=\text { Total no. of stream segments of order " } u \text { " }\end{array}$ & {$[9]$} \\
\hline 4 & Stream Length Ratio $(R L)$ & $\begin{array}{l}R L=L u / L u-1 \text {; Where, } R L=\text { Stream length ratio; } L u=\text { The total stream length of } \\
\text { order " } u \text { "; } L u-1=\text { The total stream length of its next lower order }\end{array}$ & [22] \\
\hline 5 & Bifurcation Ratio $(R b)$ & $\begin{array}{l}R b=N u / N u+1 \text {; Where, } R b=\text { Bifucation ratio; } N u=\text { Total no. of stream segments } \\
\text { of order " } u \text { "; } N u+1=\text { Number of segments of the next higher order }\end{array}$ & [23] \\
\hline 6 & Mean Bifurcation Ratio (Rbm) & $R b m=$ Average of bifurcation ratios of all orders & {$[10]$} \\
\hline 7 & Relief Ratio $(R h)$ & $\begin{array}{l}R h=H / L ; \text { Where, } R h=\text { Relief ratio; } H=\text { Total relief (Relative relief) of the basin in } \\
\text { Kilometre; } L b=\text { Basin length }\end{array}$ & [23] \\
\hline 8 & Drainage Density $(D)$ & $\begin{array}{l}D=L u / A ; \text { Where, } D=\text { Drainage density; } L u=\text { Total stream length of all orders; } A= \\
\text { Area of the basin }\left(\mathrm{km}^{2}\right)\end{array}$ & {$[24]$} \\
\hline 9 & Stream Frequency $(F s)$ & $\begin{array}{l}F s=N u / A ; \text { Where, } F s=\text { Stream frequency; } N u=\text { Total no. of streams of all orders; } \\
A=\text { Area of the basin }\left(\mathrm{km}^{2}\right)\end{array}$ & [24] \\
\hline 10 & Drainage Texture $(R t)$ & $\begin{array}{l}R t=N u / P ; \text { Where, } R t=\text { Drainage texture; } N u=\text { Total no. of streams of all orders; } \\
P=\text { Perimeter }(\mathrm{km})\end{array}$ & {$[22]$} \\
\hline 11 & Form Factor $(R f)$ & $\begin{array}{l}R f=A / L b^{2} ; \text { Where, } R f=\text { Form factor; } A=\text { Area of the basin }\left(\mathrm{km}^{2}\right) ; L b^{2}=\text { Square } \\
\text { of basin length }\end{array}$ & {$[24]$} \\
\hline 12 & Circularity Ratio $(R c)$ & $\begin{array}{l}R c=4 * \pi * A / p^{2} ; \text { Where, } R e=\text { Circularity ratio; } \pi=\text { " } P i \text { " value that is } 3.14 ; A=\text { Area } \\
\text { of the basin }\left(\mathrm{km}^{2}\right) ; P=\text { Perimeter }(\mathrm{km})\end{array}$ & [25] \\
\hline 13 & Elongation Ratio $(R e)$ & $\begin{array}{l}\operatorname{Re}=(2 / L b)^{*} \operatorname{sqrt}(A / \pi) ; \text { Where, } \mathrm{Re}=\text { Elongation ratio } A=\text { Area of the basin }\left(\mathrm{km}^{2}\right) \\
\pi=\text { " } P i \text { " value that is } 3.14 ; L b=\text { Basin length }\end{array}$ & [23] \\
\hline 14 & Length of overland flow $(\mathrm{Lg})$ & $L g=1 / D * 2$; Where, $L g=$ Length of overland flow; $D=$ Drainage density & {$[22]$} \\
\hline 15 & $\begin{array}{l}\text { Constant Channel } \\
\text { Maintenance }(C)\end{array}$ & $C=1 / D$; Where, $D=$ Drainage density & [23] \\
\hline 16 & Texture Ratio $(T)$ & $T=N 1 / P ;$ Where, $N 1=$ Total number of streams in 1st order; $P=$ Perimeter of basin & [23] \\
\hline 17 & Shape index $(S w)$ & $S w=L b^{2} / A$; Where, $L b=$ Basin length; $A=$ Area of basin & {$[22]$} \\
\hline 18 & Ruggedness number $(R n)$ & $R n=B h * D$; Where, $B h=$ Basin relief; $D=$ Drainage density & {$[26]$} \\
\hline 19 & Shape Factor $(R s)$ & $\begin{array}{l}R s=P u / P c \text {; Where, } P u=\text { Perimeter of circle of watershed area; } P c=\text { Perimeter of } \\
\text { watershed }\end{array}$ & [27] \\
\hline 20 & Drainage Intensity $(D i)$ & $D i=F s / D d ;$ Where,$F s=$ Stream frequency; $D d=$ Drainage density & [28] \\
\hline 21 & Compactness coefficient $(C c)$ & $\begin{array}{l}C c=P c / P u \text {; Where, } P c=\text { Perimeter of watershed; } P u=\text { Perimeter of circle of } \\
\text { watershed area }\end{array}$ & {$[19]$} \\
\hline
\end{tabular}

the present study as depicted in Table $7, R h$ ranges from a minimum of 0.14 in WS9 to a maximum of 0.61 in WS17. Higher values of $R h$ indicate that intense erosion processes are taking place. This indicates that WS17 is more susceptible to erosion, and WS9 is the least among all the subwatersheds of the study area if this parameter alone is considered for erosion intensity analysis.

3.6. Drainage Density (D). Factors which affect $D$ are characteristically same as those affecting length of the stream, namely, resistance to weathering, permeability of rock formation, climate, vegetation, and so forth. The travel time by water within the basin is controlled by $D$ [49-51]. In humid regions, it varies between 0.55 and $2.09 \mathrm{~km} / \mathrm{km}^{2}$ [52]. Generally, $D$ has a low value in regions underlain with highly resistant permeable material with vegetative cover and low relief. High drainage density is observed in the regions of weak and impermeable subsurface material and sparse vegetation and mountainous relief. Perusal of the $D$ values from Table 5 indicates that WS17, WS14, and WS11 have low $D$ values (below $2.0 \mathrm{~km} / \mathrm{km}^{2}$ ), while WS1, WS15, 
TABLE 2: Some important basin characteristics.

\begin{tabular}{|c|c|c|c|c|c|c|c|}
\hline Subwatersheds & $\begin{array}{l}\text { Minimum } \\
\text { elevation } \\
(\mathrm{km})\end{array}$ & $\begin{array}{c}\text { Maximum } \\
\text { elevation } \\
(\mathrm{km})\end{array}$ & Relative relief & Perimeter $(\mathrm{km})$ & Basin area $\left(\mathrm{km}^{2}\right)$ & Basin length $(\mathrm{km})$ & Longest flow path $(\mathrm{km})$ \\
\hline WS1 & 2.10 & 3.57 & 1.47 & 18.30 & 10.45 & 3.52 & 4.03 \\
\hline WS2 & 2.25 & 3.56 & 1.32 & 15.84 & 10.88 & 5.29 & 6.79 \\
\hline WS3 & 2.25 & 3.56 & 1.32 & 15.84 & 10.88 & 14.29 & 17.68 \\
\hline WS4 & 2.50 & 4.42 & 1.93 & 17.71 & 11.94 & 3.36 & 4.34 \\
\hline WS5 & 2.83 & 4.26 & 1.43 & 9.52 & 4.28 & 2.95 & 3.40 \\
\hline WS6 & 2.92 & 4.89 & 1.97 & 21.54 & 19.78 & 6.33 & 7.06 \\
\hline WS7 & 3.05 & 5.29 & 2.24 & 33.10 & 48.17 & 12.09 & 14.95 \\
\hline WS8 & 3.04 & 4.75 & 1.71 & 30.55 & 37.58 & 8.87 & 10.74 \\
\hline WS9 & 2.53 & 4.62 & 2.10 & 54.04 & 88.15 & 14.71 & 16.77 \\
\hline WS10 & 2.49 & 4.37 & 1.88 & 30.00 & 41.76 & 11.09 & 12.98 \\
\hline WS11 & 2.41 & 4.23 & 1.82 & 17.09 & 11.72 & 6.33 & 8.14 \\
\hline WS12 & 2.30 & 4.29 & 1.99 & 16.67 & 9.52 & 6.09 & 6.88 \\
\hline WS13 & 2.26 & 4.37 & 2.11 & 17.92 & 10.50 & 4.06 & 7.82 \\
\hline WS14 & 2.25 & 4.03 & 1.78 & 11.61 & 6.55 & 7.90 & 9.62 \\
\hline WS15 & 2.23 & 4.27 & 2.04 & 21.09 & 15.60 & 4.35 & 5.51 \\
\hline WS16 & 2.16 & 4.20 & 2.04 & 12.98 & 8.30 & 2.17 & 2.34 \\
\hline WS17 & 2.08 & 3.40 & 1.31 & 9.90 & 4.61 & 2.17 & 2.34 \\
\hline
\end{tabular}

TABLE 3: Showing stream order, stream number, and stream lengths of subwatersheds.

\begin{tabular}{lccccccccccc}
\hline \multirow{2}{*}{ Subwatershed } & \multirow{2}{*}{ Stream order } & \multicolumn{4}{c}{ Stream number } & \multicolumn{4}{c}{ Stream length (km) } \\
& & I & II & III & IV & V & I & II & III & IV & V \\
\hline WS1 & 4 & 46 & 12 & 3 & 1 & - & 13.63 & 3.50 & 4.05 & 0.84 \\
WS2 & 4 & 44 & 9 & 2 & 1 & - & 13.63 & 3.81 & 7.01 & 1.94 & - \\
WS3 & 5 & 253 & 71 & 14 & 3 & 1 & 82.60 & 19.39 & 20.44 & 17.49 & 2.79 \\
WS4 & 4 & 53 & 13 & 2 & 1 & - & 18.11 & 5.54 & 4.25 & 0.15 \\
WS5 & 4 & 19 & 8 & 2 & 1 & - & 6.43 & 1.71 & 1.60 & 0.86 \\
WS6 & 4 & 86 & 35 & 7 & 1 & - & 28.61 & 12.82 & 5.36 & 5.34 \\
WS7 & 5 & 218 & 106 & 12 & 2 & 1 & 83.13 & 34.62 & 19.93 & 3.01 \\
WS8 & 5 & 195 & 92 & 10 & 2 & 1 & 61.74 & 25.06 & 14.73 & 8.82 \\
WS9 & 5 & 437 & 225 & 21 & 5 & 1 & 132.17 & 66.02 & 26.08 & 12.57 & 7.76 \\
WS10 & 5 & 171 & 99 & 7 & 2 & 1 & 55.62 & 26.89 & 6.31 & 11.93 \\
WS11 & 4 & 40 & 10 & 2 & 1 & - & 11.78 & 3.15 & 2.60 & 4.22 \\
WS12 & 3 & 60 & 17 & 1 & - & - & 17.97 & 4.47 & 5.61 & - \\
WS13 & 3 & 59 & 14 & 1 & - & - & 20.26 & 4.66 & 6.70 & - \\
WS14 & 3 & 20 & 6 & 1 & - & - & 8.34 & 2.45 & 0.72 & - \\
WS15 & 4 & 67 & 17 & 3 & 1 & - & 20.84 & 5.37 & 2.10 & 6.21 \\
WS16 & 3 & 39 & 10 & 2 & - & - & 12.27 & 2.32 & 4.62 & - \\
WS17 & 2 & 12 & 4 & - & - & - & 3.39 & 2.05 & - \\
\hline
\end{tabular}

WS16, WS4, WS3, WS2, WS5, and WS10 have moderate $D$ values $\left(2.0-2.5 \mathrm{~km} / \mathrm{km}^{2}\right)$. Subwatersheds WS6, WS9, WS12, WS7, WS8, and WS13 have high $D$ values (between 2.5 and $3.0 \mathrm{~km} / \mathrm{km}^{2}$ ). The low and moderate $D$ watersheds reveal that they are composed of permeable subsurface material, good vegetation cover, and low relief which results in more infiltration capacity and comparably are good sites for ground water recharge as compared to high $D$ watersheds $[53,54]$.
On the basis of $D$, WS17 will have the greatest basin lag time, while WS13 will demonstrate the shortest lag time.

3.7. Drainage Texture (Rt). Drainage texture $(R t)$ is influenced by infiltration capacity [22]. There are five different texture classes: very coarse $(<2)$, coarse $(2-4)$, moderate (4-6), fine (6-8), and very fine (>8) [55]. According to this 
TABLE 4: Showing comparative mean stream length and stream length ratios.

\begin{tabular}{|c|c|c|c|c|c|c|c|c|c|}
\hline \multirow{2}{*}{ Subwatershed } & \multicolumn{5}{|c|}{ Mean stream length $(\mathrm{km})$} & \multicolumn{4}{|c|}{ Stream length ratio } \\
\hline & $\mathrm{I}$ & II & III & IV & $\mathrm{V}$ & II/I & $\mathrm{III} / \mathrm{II}$ & IV/III & $\mathrm{V} / \mathrm{IV}$ \\
\hline WS1 & 0.29 & 0.29 & 1.35 & 0.84 & - & 0.25 & 1.15 & 0.20 & - \\
\hline WS2 & 0.30 & 0.42 & 3.50 & 1.94 & - & 0.27 & 1.84 & 0.27 & - \\
\hline WS3 & 0.32 & 0.27 & 1.46 & 5.83 & 2.79 & 0.23 & 1.05 & 0.85 & 0.15 \\
\hline WS4 & 0.34 & 0.42 & 2.12 & 0.15 & - & 0.30 & 0.76 & 0.03 & - \\
\hline WS5 & 0.33 & 0.21 & 0.79 & 0.86 & - & 0.26 & 0.93 & 0.53 & - \\
\hline WS6 & 0.33 & 0.36 & 0.76 & 5.34 & - & 0.44 & 0.41 & 0.99 & - \\
\hline WS7 & 0.38 & 0.32 & 1.66 & 1.50 & 1.76 & 0.41 & 0.57 & 0.15 & 0.58 \\
\hline WS8 & 0.31 & 0.27 & 1.47 & 4.41 & 1.76 & 0.40 & 0.58 & 0.59 & 0.19 \\
\hline WS9 & 0.30 & 0.29 & 1.24 & 2.51 & 7.76 & 0.49 & 0.39 & 0.48 & 0.61 \\
\hline WS10 & 0.32 & 0.27 & 0.90 & 5.96 & 3.31 & 0.48 & 0.23 & 1.89 & 0.27 \\
\hline WS11 & 0.29 & 0.31 & 1.30 & 4.22 & - & 0.26 & 0.82 & 1.62 & - \\
\hline WS12 & 0.29 & 0.26 & 5.61 & - & - & 0.24 & 1.25 & - & - \\
\hline WS13 & 0.34 & 0.33 & 6.69 & - & - & 0.23 & 1.43 & - & - \\
\hline WS14 & 0.41 & 0.40 & 0.71 & - & - & 0.29 & 0.29 & - & - \\
\hline WS15 & 0.31 & 0.31 & 0.69 & 6.20 & - & 0.25 & 0.39 & 2.96 & - \\
\hline WS16 & 0.31 & 0.23 & 2.31 & - & - & 0.18 & 1.99 & - & - \\
\hline WS17 & 0.28 & 0.51 & - & - & - & 0.60 & - & - & - \\
\hline
\end{tabular}

TABLE 5: Showing bifurcation ratios, drainage density, and stream frequency of the subwatersheds.

\begin{tabular}{|c|c|c|c|c|c|c|c|c|}
\hline \multirow{2}{*}{ Subwatershed } & \multicolumn{4}{|c|}{ Bifurcation ratio } & \multirow{2}{*}{ Mean bifurcation ratio } & \multirow{2}{*}{ Drainage density } & \multirow{2}{*}{ Stream frequency } & \multirow{2}{*}{ Drainage intensity } \\
\hline & $\mathrm{I} / \mathrm{II}$ & II/III & III/IV & $\mathrm{IV} / \mathrm{V}$ & & & & \\
\hline WS1 & 3.83 & 4.00 & 3.00 & - & 3.61 & 2.11 & 5.93 & 2.82 \\
\hline WS2 & 4.89 & 4.50 & 2.00 & - & 3.80 & 2.43 & 5.15 & 2.12 \\
\hline WS3 & 3.56 & 5.07 & 4.67 & 3.00 & 4.08 & 2.36 & 5.63 & 2.39 \\
\hline WS4 & 4.08 & 6.50 & 2.00 & - & 4.19 & 2.35 & 5.78 & 2.46 \\
\hline WS5 & 2.38 & 4.00 & 2.00 & - & 2.79 & 2.48 & 7.02 & 2.83 \\
\hline WS6 & 2.46 & 5.00 & 7.00 & - & 4.82 & 2.64 & 6.52 & 2.47 \\
\hline WS7 & 2.06 & 8.83 & 6.00 & 2.00 & 4.72 & 2.96 & 7.04 & 2.38 \\
\hline WS8 & 2.12 & 9.20 & 5.00 & 2.00 & 4.58 & 2.98 & 7.98 & 2.68 \\
\hline WS9 & 1.94 & 10.71 & 4.20 & 5.00 & 5.62 & 2.69 & 7.82 & 2.91 \\
\hline WS10 & 1.73 & 14.14 & 3.50 & 2.00 & 5.34 & 2.49 & 6.70 & 2.69 \\
\hline WS11 & 4.00 & 5.00 & 2.00 & - & 3.67 & 1.86 & 4.52 & 2.44 \\
\hline WS12 & 3.53 & 17.00 & - & - & 10.26 & 2.95 & 8.19 & 2.78 \\
\hline WS13 & 4.21 & 14.00 & - & - & 9.11 & 3.01 & 7.05 & 2.34 \\
\hline WS14 & 3.33 & 6.00 & - & - & 4.67 & 1.76 & 4.12 & 2.35 \\
\hline WS15 & 3.94 & 5.67 & 3.00 & - & 4.20 & 2.21 & 5.64 & 2.55 \\
\hline WS16 & 3.90 & 5.00 & - & - & 4.45 & 2.32 & 6.15 & 2.65 \\
\hline WS17 & 3.00 & - & - & - & 3.00 & 1.18 & 3.47 & 2.94 \\
\hline
\end{tabular}

classification, WS17 has very coarse drainage texture, WS1, WS2, WS4, WS5, WS11, WS14, and WS16 have coarse Rt, WS3, WS6, WS12, WS13, and WS15 have moderate $R t$, and WS7, WS8, WS9, and WS10 have very fine Rt (Table 6). Hydrologically very coarse texture watersheds have large basin lag time periods [56] followed by coarse, fine, and very fine texture classes. This indicates that WS17 $(R t=1.62)$ shows longer duration to peak flow, while WS9 $(R t=12.75)$ shows the shortest.
3.8. Form Factor $(R f)$. The basins with high form factors have high peak flows of shorter duration, whereas elongated subwatersheds with low form factors have lower peak flow of longer duration [57-59]. In this study, WS2, WS3, WS7, WS10, WS11, WS13, WS14, and WS15 show lower form factor (Table 7) indicating elongated shape and suggesting flat hydrograph peak for longer duration. Flood flows of such elongated basins are easier to manage than those of the circular basin. WS5, WS6, WS8, WS9, WS12, and WS16 have 
TABLE 6: Showing drainage texture, constant channel maintenance, shape index, ruggedness number, and shape factor.

\begin{tabular}{|c|c|c|c|c|c|c|}
\hline Subwatershed & Drainage texture & $\begin{array}{l}\text { Constant channel } \\
\text { maintenance }\end{array}$ & $\begin{array}{c}\text { Compactness } \\
\text { coefficient }\end{array}$ & Shape index & Ruggedness number & Shape factor \\
\hline WS1 & 3.39 & 0.47 & 1.60 & 1.19 & 0.70 & 0.63 \\
\hline WS2 & 3.54 & 0.41 & 1.36 & 2.57 & 0.54 & 0.74 \\
\hline WS3 & 5.63 & 0.42 & 2.20 & 3.37 & 1.19 & 0.46 \\
\hline WS4 & 3.90 & 0.43 & 1.45 & 0.94 & 0.82 & 0.69 \\
\hline WS5 & 3.15 & 0.40 & 1.30 & 2.03 & 0.58 & 0.77 \\
\hline WS6 & 5.99 & 0.38 & 1.37 & 2.03 & 0.75 & 0.73 \\
\hline WS7 & 10.24 & 0.34 & 1.35 & 3.03 & 0.76 & 0.74 \\
\hline WS8 & 9.82 & 0.34 & 1.41 & 2.09 & 0.57 & 0.71 \\
\hline WS9 & 12.75 & 0.37 & 1.62 & 2.46 & 0.78 & 0.62 \\
\hline WS10 & 9.33 & 0.40 & 1.31 & 2.95 & 0.75 & 0.76 \\
\hline WS11 & 3.10 & 0.54 & 1.41 & 3.42 & 0.98 & 0.71 \\
\hline WS12 & 4.68 & 0.34 & 1.52 & 3.90 & 0.67 & 0.66 \\
\hline WS13 & 4.13 & 0.33 & 1.56 & 4.02 & 0.70 & 0.64 \\
\hline WS14 & 2.33 & 0.57 & 1.28 & 2.52 & 1.01 & 0.78 \\
\hline WS15 & 4.17 & 0.45 & 1.51 & 4.00 & 0.92 & 0.66 \\
\hline WS16 & 3.93 & 0.43 & 1.27 & 2.28 & 0.88 & 0.79 \\
\hline WS17 & 1.62 & 0.85 & 1.30 & 1.02 & 1.11 & 0.77 \\
\hline
\end{tabular}

TABLE 7: Showing important morphometric parameters of the subwatersheds.

\begin{tabular}{|c|c|c|c|c|c|c|}
\hline Subwatershed & Relief ratio & Elongation ratio & Texture ratio & Circularity ratio & Form factor & Length of overland flow \\
\hline WS1 & 0.42 & 1.04 & 2.51 & 0.39 & 0.84 & 0.23 \\
\hline WS2 & 0.25 & 0.70 & 2.78 & 0.54 & 0.39 & 0.17 \\
\hline WS3 & 0.20 & 0.61 & 4.18 & 0.21 & 0.30 & 0.18 \\
\hline WS4 & 0.57 & 1.16 & 2.99 & 0.48 & 1.06 & 0.18 \\
\hline WS5 & 0.49 & 0.79 & 2.00 & 0.59 & 0.49 & 0.16 \\
\hline WS6 & 0.31 & 0.79 & 3.99 & 0.54 & 0.49 & 0.14 \\
\hline WS7 & 0.19 & 0.65 & 6.59 & 0.55 & 0.33 & 0.11 \\
\hline WS8 & 0.19 & 0.78 & 6.38 & 0.51 & 0.48 & 0.11 \\
\hline WS9 & 0.14 & 0.72 & 8.09 & 0.38 & 0.41 & 0.14 \\
\hline WS10 & 0.17 & 0.66 & 5.70 & 0.58 & 0.34 & 0.16 \\
\hline WS11 & 0.29 & 0.61 & 2.34 & 0.50 & 0.29 & 0.29 \\
\hline WS12 & 0.33 & 0.57 & 3.60 & 0.43 & 0.26 & 0.12 \\
\hline WS13 & 0.32 & 0.56 & 3.29 & 0.41 & 0.25 & 0.11 \\
\hline WS14 & 0.44 & 0.71 & 1.72 & 0.61 & 0.40 & 0.32 \\
\hline WS15 & 0.26 & 0.56 & 3.18 & 0.44 & 0.25 & 0.20 \\
\hline WS16 & 0.47 & 0.75 & 3.01 & 0.62 & 0.44 & 0.19 \\
\hline WS17 & 0.61 & 1.12 & 1.21 & 0.59 & 0.98 & 0.72 \\
\hline
\end{tabular}

slightly circular shape as suggested by moderately higher $R f$. Subwatersheds WS1, WS4, and WS17 have high $R f$ indicating that they have developed into quite circular to rectangular shape. Watershed morphology has profound impacts on the watershed hydrology [60].

3.9. Elongation Ratio ( $R e$ ). The value of elongation ratio $(R e)$ generally varies from 0.6 to 1.0 associated with a wide variety of climate and geology. Values close to 1.0 are typical of regions of very low relief whereas, that from 0.6 to 0.8 are associated with high relief and steep ground slope [7]. These values can be grouped into three categories, namely, circular (>0.9), oval (0.9-0.7), and less elongated $(<0.7)$. Re for the subwatersheds WS13, WS15, WS12, WS3, WS11, WS7, and WS10 is less than 0.70 which indicates that subwatersheds are elongated with high relief and steep slope. WS2, WS14, WS9, WS16, WS8, WS5, and WS6 sub-watersheds fall in oval 


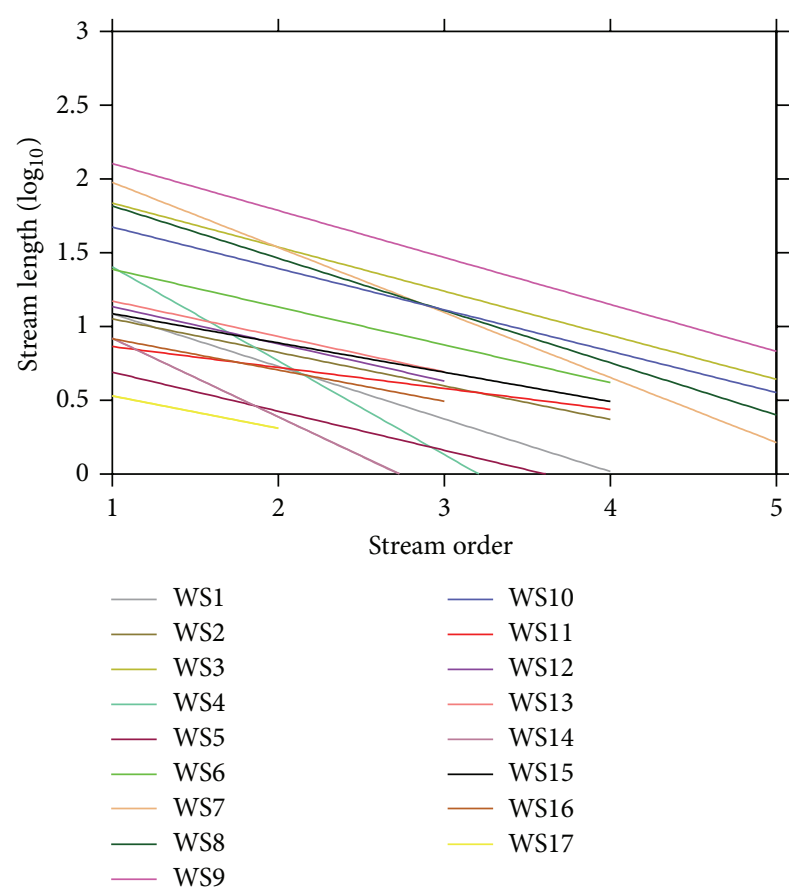

FIGURE 3: Showing relation between stream order and length of streams for 17 subwatersheds.

category, while subwatersheds WS1, WS17 and WS4 fall in the circular category (Table 7). The circular watersheds have quick, though lower, hydrograph peak compared to the oval and elongated watersheds $[61,62]$. This indicates that WS13 will show delayed time to peak flow, while WS4 will show shorter time to peak.

3.10. Circulatory Ratio $(R c)$. It is that ratio of the area of the basin to the area of circle having the same circumference as the perimeter of the basin [25]. Many of the important basin characteristics influence Rc such as length and frequency of streams, geological structures, land use/land cover, climate, relief, and slope of the basin. In the present case, $R c$ for subwatersheds WS8, WS2, WS6, WS7, WS10, WS5, WS17, WS14, and WS16 is in the range from 0.53 to 0.62 indicating that the area is characterized by high relief, elongated, and permeable surface resulting in greater basin lag times, while WS3, WS9, WS1, WS13, WS12, WS15, WS4, and WS11 have lower circularity ratios indicating low relief and impermeable surface resulting in lower basin lag times (Table 7). This indicates that WS16 will show delayed time to peak flow, while WS3 will show shorter time to peak. $R f, R e$, and $R c$ significantly influence the hydrological response of the watersheds as basin shape, and the arrangement of stream segments combine to influence the size and shape of flood peaks [63].

3.11. Length of Overland Flow ( $\mathrm{Lg}$ ). Length of overland flow is one of the most important independent variables affecting both hydrologic and hydrographic development of drainage basins [24]. Table 7 reveals that $\mathrm{Lg}$ for the 17 subwatersheds in chronological order is $0.22,0.16,0.18,0.18,0.16,0.14,0.11,0.11$, $0.76,0.16,0.29,0.11,0.11,0.32,0.2,0.18$, and 0.71 , respectively. The $L g$ for subwatersheds WS2-WS10, WS12, WS13, and WS16 indicates steep slopes and shorter flow paths, while as $\mathrm{Lg}$ for WS1, WS11, WS14, WS15, and WS17 indicates gentle slopes and longer flow paths.

3.12. Constant of Channel Maintenance (C). In the present study, $C$ varies from 0.33 for W8 and W9 to 0.84 for W17 as is shown in Table 6 . The reciprocal of the drainage density $(D)$ is constant of channel maintenance and signifies how much drainage area is required to maintain a unit length of channel. Low values of $C$ in case of WS8 and WS9 indicates that among all the 17 subwatersheds, these two are associated with weakest or very low-resistance soils, sparse vegetation and mountainous terrain, while the watershed WS17 is associated with resistance soils, vegetation and comparably plain terrain [64].

3.13. Compactness Coefficient (Cc). Compactness coefficient expresses the relationship of a basin with that of a circular basin having the same area. A circular basin yields the shortest time of concentration before peak flow occurs in the basin. $C c=1$ indicates that the basin completely behaves as a circular basin. $C c>1$ indicates more deviation from the circular nature of the basin. The values for all the subwatersheds range from 1.27 for WS16 to 2.20 for WS3, as seen in Table 6. Consequently, WS16 has the greatest deviation from the circular nature, and on the basis of this parameter alone, it will have the longest time of concentration before peak flow occurs in the basin out of all the subwatersheds [60-62].

3.14. Shape Index $(S w)$. Rate of water and sediment yield along the length and relief of the drainage basin is largely affected by the shape. The shape index values for subwatersheds of the study area range from 0.94 in WS4 to 4.02 in WS13 as shown in Table 6. In terms of $S w$ only, WS13 will have the shorter basin lag time, while WS4 will have the longer basin lag time.

3.15. Texture Ratio (T). Texture ratio is one of the most important factors in the drainage morphometric analysis, which depends on the underlying lithology infiltration capacity, and relief aspect of the terrain is the texture ratio $[65,66]$. As shown in Table 7, $T$ varies between 1.21 in case of WS17 and 8.09 in case of WS9. Hydrologically, it can be said that WS17 in terms of Talone will have the longest basin lag times and WS9 will have the shortest. This reaffirms the results and conclusions drawn from the values of $U, D, F s$, and $R t$ in case of W17.

3.16. Ruggedness Number (Rn). The ruggedness number indicates the structural complexity of the terrain in association with the relief and drainage density. It also implies that the area is susceptible to soil erosion $[67,68]$. In present study, the ruggedness number is minimum in case of WS2 $(R n=0.54)$ and maximum in WS3 $(R n=1.19)$ as seen in Table 6 . This indicates that WS2 is least susceptible to erosion and WS3 

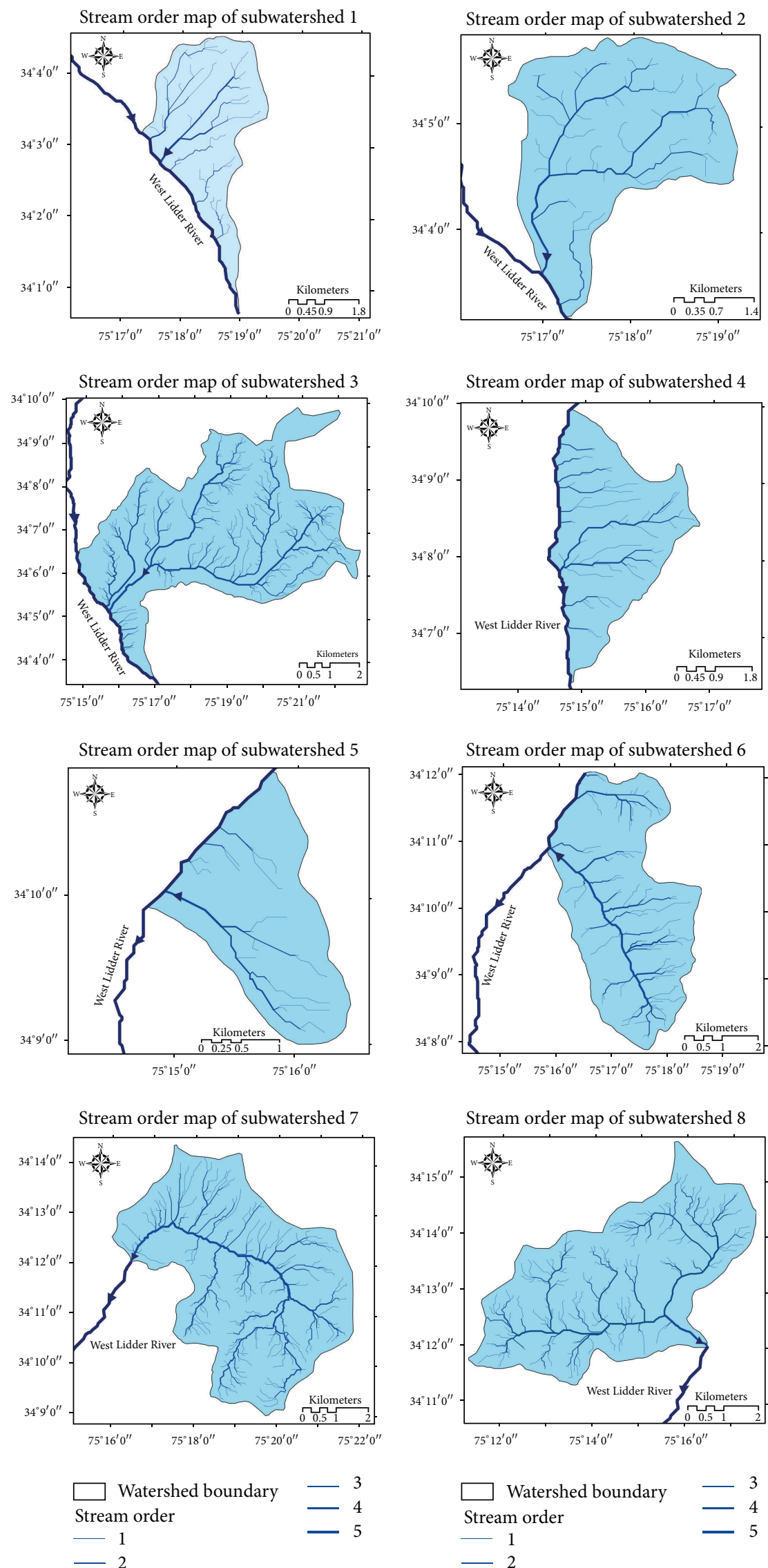

(a)

Figure 4: Continued. 

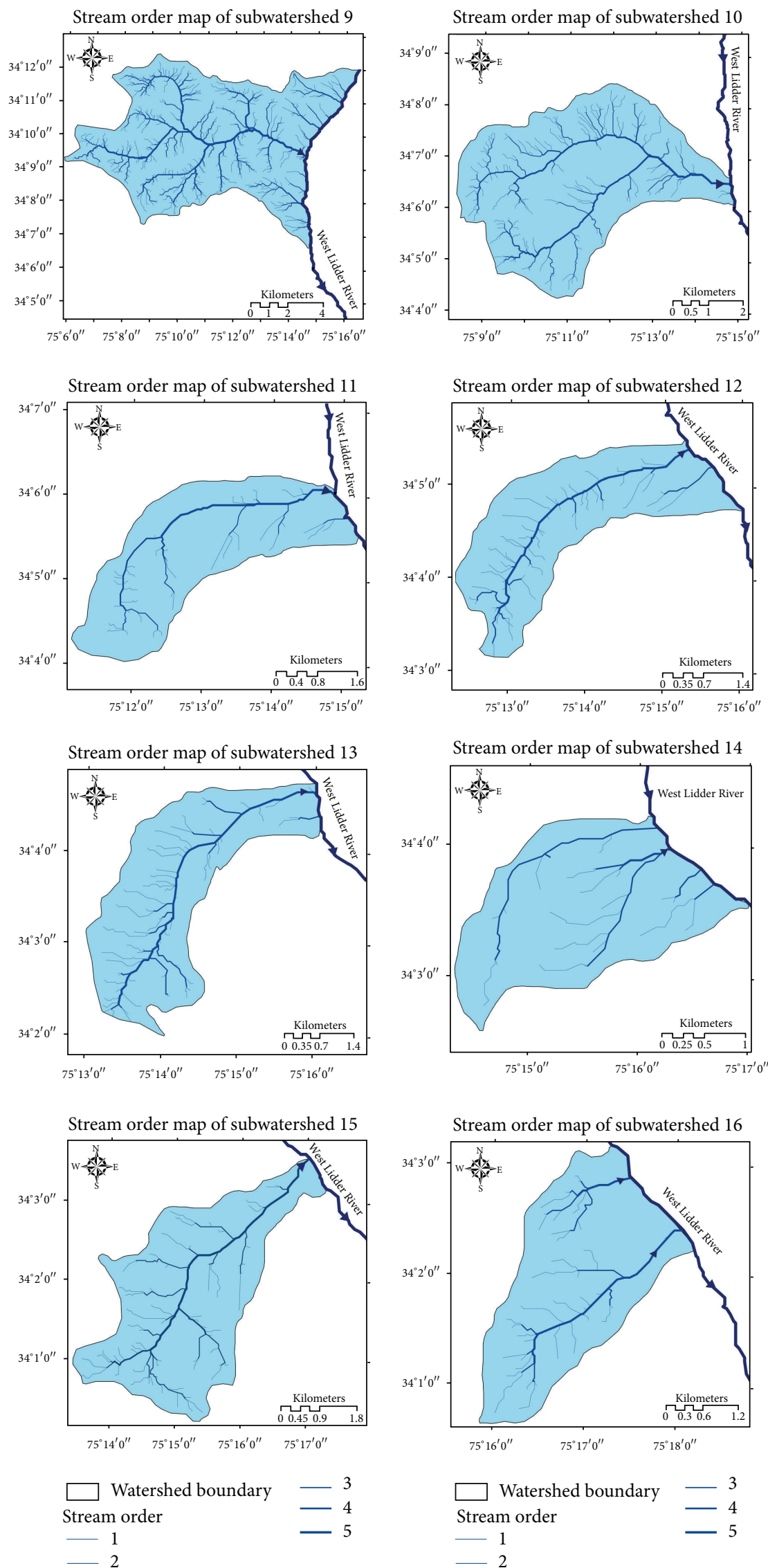

(b)

Figure 4: Continued. 


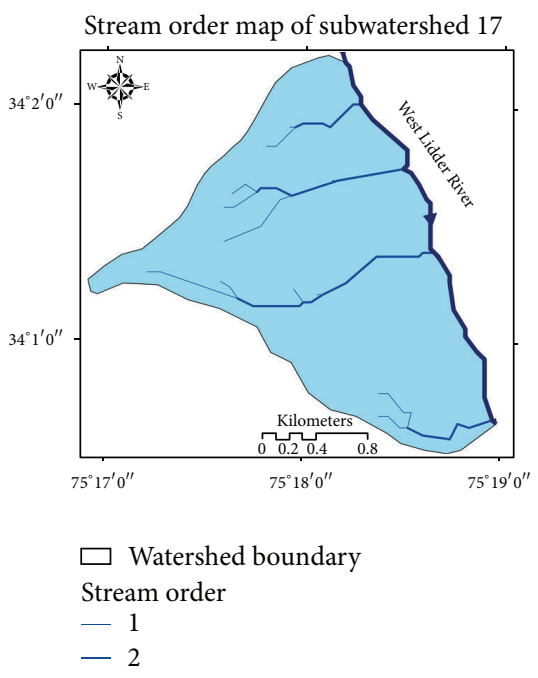

(c)

FIgURE 4: (a) Showing drainage maps of subwatersheds, WS1-WS8. (b) Showing drainage maps of subwatersheds, WS9-WS16. (c) Showing drainage patterns of WS17 of West Lidder catchment.

is most susceptible among all the subwatersheds of the study area.

3.17. Shape Factor (Rs). The shape factor observed in the study area is minimum in case of WS3 $(R s=0.46)$ and maximum in case of WS16 ( $R s=0.79)$, as shown in Table 6. This parameter is similar in interpretation to circularity ratio, elongation ratio, and form factor. It gives an idea about the circular character of the basin. The greater the circular character of the basin is, the greater is the rapid response of the watershed after a storm event [60]. Therefore, in terms of Rs only, WS3 has the longest basin lag time, and WS16 the shortest.

\section{Conclusion}

From the integrated analysis of the results on the morphometry of the 17 subwatersheds, it is concluded that the whole study area has uniform underlying lithology making the hydrological response in these subwatersheds a direct function of the geomorphology, the topography, and the existing vegetation conditions only. The spatial variability of the morphometric parameters analyzed in this study is quite significant. Since, the hydrology of a watershed changes significantly due to the spatial variations of the morphometric parameters, the subwatersheds will therefore also exhibit differential hydrological behaviour. Overall results indicated that comparatively WS16, WS13, WS12, and WS9 shall contribute dominantly to the stream runoff in the West Lidder catchment, and on the contrary, WS17, WS5, and WS3 shall contribute the least due to the cumulative and integrated effect of the morphometric parameters whose significance and influences on the hydrological behaviour have been discussed in detail in the preceding sections. Because of the close relationship between the morphometric parameters and the mean annual flood, it is concluded, on the basis of the range of the morphometric analysis, that WS16, WS13, WS12, and WS9, in that order, are more prone to flooding compared to the other 13 subwatersheds of the West Lidder catchment. The hydrological behaviour of these 17 subwatersheds shall have profound influences on the flood vulnerability and flood risk in the downstream portions of the Lidder River. It is hoped that information and knowledge generated under this study shall guide the informed planning and decision-making for flood disaster risk reduction in the Lidder watershed that forms an important tributary of the Jhelum basin.

\section{Acknowledgments}

This research work has been accomplished under a research grant provided by the Department of Science and Technology, Government of India for the project titled "Integrated Flood vulnerability Assessment for Flood Risk Management and Disaster Mitigation." The authors express their gratitude to the funding agency for the financial assistance. The authors also express their sincere thanks to anonymous reviewers whose valuable comments have improved the quality of this paper.

\section{References}

[1] C. S. Agarwal, "Study of drainage pattern through aerial data in Naugarh area of Varanasi district, U.P.," Journal of the Indian Society of Remote Sensing, vol. 26, no. 4, pp. 169-175, 1998.

[2] G. E. Obi Reddy, A. K. Maji, and K. S. Gajbhiye, "GIS for morphometric analysis of drainage basins," GIS India, vol. 11, no. 4, pp. 9-14, 2002.

[3] V. Pakhmode, H. Kulkarni, and S. B. Deolankar, "Hydrologicaldrainage analysis in watershed-programme planning: a case from the Deccan basalt, India," Hydrogeology Journal, vol. 11, no. 5, pp. 595-604, 2003. 
[4] L. B. Leopold and T. Maddock, "The hydraulic geometry of stream channels and some physiographic implications," USGS Professional Paper, vol. 252, pp. 1-57, 1953.

[5] A. D. Abrahams, "Channel networks: a geomorphological perspective," Water Resources Research, vol. 20, no. 2, pp. 161$168,1984$.

[6] S. Singh, "Quantitative geomorphology of the drainage basin," in Readings on Remote Sensing Applications, T. S. Chouhan and K. N. Joshi, Eds., Scientific Publishers, Jodhpur, India, 1992.

[7] R. A. Dar, R. Chandra, and S. A. Romshoo, "Morphotectonic and lithostratigraphic analysis of intermontane Karewa basin of Kashmir Himalayas, India," Journal of Mountain Science, vol. 10, no. 1, pp. 731-741, 2013.

[8] S. A. Romshoo, S. A. Bhat, and I. Rashid, "Geoinformatics for assessing the morphometric control on hydrological response at watershed scale in the Upper Indus basin," Journal of Earth System Science, vol. 121, no. 3, pp. 659-686, 2012.

[9] A. N. Strahler, "Quantitative geomorphology of drainage basins and channel networks," in Handbook of Applied Hydrology, V. T. Chow, Ed., section 4-11, McGraw-Hill, New York, NY, USA, 1964.

[10] A. Strahler, "Quantitative analysis of watershed geomorphology," Transactions American Geophysical Union, vol. 38, pp. 913920, 1957.

[11] J. Krishnamurthy, G. Srinivas, V. Jayaraman, and M. G. Chandrasekhar, "Influence of rock types and structures in the development of drainage networks in typical hardrock terrain," ITC Journal, no. 3-4, pp. 252-259, 1996.

[12] A. K. Das and S. Mukherjee, "Drainage morphometry using satellite data and GIS in Raigad district, Maharashtra," Journal of the Geological Society of India, vol. 65, no. 5, pp. 577-586, 2005.

[13] S. S. Vittala, S. Govindaih, and H. H. Gowda, "Morphometric analysis of sub-watershed in the Pavada area of Tumkur district, South India using remote sensing and GIS techniques," Journal of Indian Remote Sensing, vol. 32, pp. 351-362, 2004.

[14] S. K. Nag, "Morphometric analysis using remote sensing techniques in the Chaka subbasin Purulia district, West Bengal," Journal of Indian Society of Remote Sensing, vol. 26, no. 1-2, pp. 69-76, 1998.

[15] A. M. Y. Esper, "Morphometric analysis of Colanguil river basin and flash flood hazard, San Juan Argentina," Environmental Geology, vol. 55, pp. 107-111, 2008.

[16] T. N. Bhagwat, A. Shetty, and V. S. Hegde, "Spatial variation in drainage characteristics and geomorphic instantaneous unit hydrograph (GIUH); implications for watershed managementA case study of the Varada River basin, Northern Karnataka," Catena, vol. 87, no. 1, pp. 52-59, 2011.

[17] N. R. Bhaskar, B. P. Parida, and A. K. Nayak, "Flood estimation for ungauged catchments using the GIUH," Journal of Water Resources Planning and Management, vol. 123, no. 4, pp. 228237, 1997.

[18] S. K. Jain, R. D. Singh, and S. M. Seth, "Design flood estimation using GIS supported GIUH approach," Water Resources Management, vol. 14, no. 5, pp. 369-376, 2000.

[19] M. Suresh, S. Sudhakara, K. N. Tiwari, and V. M. Chowdary, "Prioritization of watersheds using morphometric parameters and assessment of surface water potential using remote sensing," Journal of the Indian Society of Remote Sensing, vol. 32, no. 3, 2004.

[20] S. A. Bhat and S. A. Romshoo, "Digital elevation model based watershed characteristics of upper watersheds of Jhelum basin," Journal of Applied Hydrology, vol. 21, no. 2, pp. 23-34, 2009.
[21] J. F. O'Callaghan and D. M. Mark, "The extraction of drainage networks from digital elevation data," Computer Vision, Graphics, and Image Processing, vol. 28, pp. 323-344, 1984.

[22] R. E. Horton, "Erosional development of streams and their drainage basins: hydrophysical approach to quantitative morphology," Geological Society of America Bulletin, vol. 56, pp. 275370, 1945.

[23] S. A. Schumms, "Evolution of drainage systems and slopes in Badlands at Perth Amboy, New Jersey," Bulletin of the Geological Society of America, vol. 67, pp. 597-646, 1956.

[24] R. E. Horton, "Drainage basin characteristics," Transactions American Geophysical Union, vol. 13, pp. 350-361, 1932.

[25] V. C. Miller, "A Quantitative geomorphic study of drainage basin characteristics in the Clinch Mountain area, Virginia and Tennessee," Tech. Rep. 3 NR 389-402, Columbia University, Department of Geology, ONR, New York, NY, USA, 1953.

[26] K. Pareta and U. Pareta, "Quantitative morphometric analysis of a watershed of Yamuna basin, India using ASTER (DEM) data and GIS," International Journal of Geomatics and Geosciences, vol. 2, no. 1, 2011.

[27] M. Sameena, J. Krishnamurthy, V. Jayaraman, and G. Ranganna, "Evaluation of drainage networks developed in hard rock terrain," Geocarto International, vol. 24, no. 5, pp. 397-420, 2009.

[28] A. Faniran, "The index of drainage intensity - a provisional new drainage factor," Australian Journal of Science, vol. 31, pp. 328330, 1968.

[29] I. Rashid and S. A. Romshoo, "Impact of anthropogenic activities on water quality of Lidder River in Kashmir Himalayas," Environmental Monitoring and Assessment, 2012.

[30] M. Raza, A. Ahmed, and A. Mohammad, The Valley of Kashmir-A Geographical Interpretation, Vol. I, the Land, Vikas Publishing, New Delhi, India, 1978.

[31] V. M. Meher, "The climate of Srinagar and its variability," Geographical Review of India, vol. 33, no. 1, pp. 1-14, 1971.

[32] B. M. Engelhardt, P. J. Weisberg, and J. C. Chambers, "Influences of watershed geomorphology on extent and composition of riparian vegetation," Journal of Vegetation Science, vol. 23, no. 1, pp. 127-139, 2011.

[33] J. E. Costa, "Hydraulics and basin morphometry of the largest flash floods in the conterminous United States," Journal of Hydrology, vol. 93, no. 3-4, pp. 313-338, 1987.

[34] S. Singh and M. C. Singh, "Morphometric analysis of Kanhar river basin," The National Geographical Journal of India, vol. 43, no. 1, pp. 31-43, 1997.

[35] W. Luo and J. M. Harlin, "A theoretical travel time based on watershed hypsometry," Journal of the American Water Resources Association, vol. 39, no. 4, pp. 785-792, 2003.

[36] J. M. Harlin, “The effect of precipitation variability on drainage basin morphometry," American Journal of Science, vol. 280, no. 8, pp. 812-825, 1980.

[37] J. M. Harlin, "Watershed morphometry and time to hydrograph peak," Journal of Hydrology, vol. 67, no. 1-4, pp. 141-154, 1984.

[38] S. A. Romshoo, "Geostatistical analysis of soil moisture measurements and remotely sensed data at different spatial scales," Environmental Geology, vol. 45, no. 3, pp. 339-349, 2004.

[39] S. A. Romshoo, M. Koike, S. Hironaka, O. Oki, and K. Musiake, "Influence of surface and vegetation characteristics on C-band radar measurements for soil moisture content," Journal of Indian Society of Remote Sensing, vol. 30, no. 4, pp. 229-244, 2002.

[40] D. R. Montgomery and W. E. Dietrich, "Source areas, drainage density, and channel initiation," Water Resources Research, vol. 25, no. 8, pp. 1907-1918, 1989. 
[41] D. R. Montgomery and W. E. Dietrich, "Channel initiation and the problem of landscape scale," Science, vol. 255, no. 5046, pp. 826-830, 1992.

[42] E. M. Ghoneim, N. W. Arnell, and G. M. Foody, "Characterizing the flash flood hazards potential along the Red Sea coast of Egypt," IAHS-AISH Publication, no. 271, pp. 211-216, 2002.

[43] M. Diakakis, "A method for flood hazard mapping based on basin morphometry: application in two catchments in Greece," Natural Hazards, vol. 56, no. 3, pp. 803-814, 2011.

[44] P. C. Patton and V. R. Baker, "Morphometry and floods in small drainage basins subject to diverse hydrogeomorphic controls," Water Resources Research, vol. 12, no. 5, pp. 941-952, 1976.

[45] A. D. Howard, "Role of hypsometry and planform in basin hydrologic response," Hydrological Processes, vol. 4, no. 4, pp. 373-385, 1990.

[46] K. Rakesh, A. K. Lohani, K. Sanjay, C. Chatterjee, and R. K. Nema, "GIS based morphometric analysis of Ajay river basin upto Srarath gauging site of South Bihar," Journal of Applied Hydrology, vol. 14, no. 4, pp. 45-54, 2000.

[47] B. Dodov and E. Foufoula-Georgiou, "Fluvial processes and streamflow variability: interplay in the scale-frequency continuum and implications for scaling," Water Resources Research, vol. 41, no. 5, pp. 1-18, 2005.

[48] L. C. Gottschalk, "Reservoir sedimentation," in Handbook of Applied Hydrology, V. T. Chow, Ed., section 7-1, McGraw-Hill, New York, NY, USA, 1964.

[49] B. A. Dodov and E. Foufoula-Georgiou, "Floodplain morphometry extraction from a high-resolution digital elevation model: a simple algorithm for regional analysis studies," IEEE Geoscience and Remote Sensing Letters, vol. 3, no. 3, pp. 410-413, 2006.

[50] P. C. Patton, "Drainage basin morphometry and floods," in Flood Geomorphology, pp. 51-64, John Wiley \& Sons, New York, NY, USA, 1988.

[51] V. Gardiner and C. C. Park, "Drainage basin morphometry," Progress in Physical Geography, vol. 2, no. 1, pp. 1-35, 1978.

[52] W. B. Langbein, "Topographic characteristics of drainage basins," U.S. Geological Survey. Water-Supply Paper, vol. 986, pp. 157-159, 1947.

[53] W. Luo, "Quantifying groundwater-sapping landforms with a hypsometric technique," Journal of Geophysical Research E: Planets, vol. 105, no. 1, pp. 1685-1694, 2000.

[54] J. M. Harlin and C. Wijeyawickrema, "Irrigation and groundwater depletion in Caddo county, Oklahoma," Journal of the American Water Resources Association, vol. 21, no. 1, pp. 15-22, 1985.

[55] K. G. Smith, "Standards for grading textures of erosional topography," American Journal of Science, vol. 248, pp. 655-668, 1950.

[56] M. Y. Esper Angillieri, "Morphometric analysis of Colangüil river basin and flash flood hazard, San Juan, Argentina," Environmental Geology, vol. 55, no. 1, pp. 107-111, 2008.

[57] A. M. Youssef, B. Pradhan, and A. M. Hassan, "Flash flood risk estimation along the St. Katherine road, southern Sinai, Egypt using GIS based morphometry and satellite imagery," Environmental Earth Sciences, vol. 62, no. 3, pp. 611-623, 2011.

[58] A. D. Howard, "Role of hypsometry and planform in basin hydrologic response," Hydrological Processes, vol. 4, no. 4, pp. 373-385, 1990.

[59] R. C. Kochel, "Geomorphic impact of large floods: review and new perspectives on magnitude and frequency," in Flood Geomorphology, pp. 169-187, John Wiley \& Sons, New York, NY, USA, 1988.
[60] G. E. Tucker and R. L. Bras, "Hillslope processes, drainage density, and landscape morphology," Water Resources Research, vol. 34, no. 10, pp. 2751-2764, 1998.

[61] M. Borga et al., "Real time guidance for flash flood risk management," FLOOD Site Research Project Report T16, 2008.

[62] K. W. Potter and E. B. Faulkner, "Catchment response time as a predictor of flood quantiles," Journal of the American Water Resources Association, vol. 23, no. 5, pp. 857-861, 1987.

[63] R. C. Ward and M. Robinson, Principles of Hydrology, McGrawHill, Maidenhead, UK, 4th edition, 2000.

[64] S. Shulits, "Quantitative formulation of stream and watershed morphology," Bulletin of the International Association of Scientific Hydrology, vol. 3, pp. 201-207, 1968.

[65] A. Demoulin, "Basin and river profile morphometry: a new index with a high potential for relative dating of tectonic uplift," Geomorphology, vol. 126, no. 1-2, pp. 97-107, 2011.

[66] T. B. Altin and B. N. Altin, "Drainage morphometry and its influence on landforms in volcanic terrain, Central Anatolia, Turkey," Procedia-Social and Behavioral Sciences, vol. 19, pp. 732-740, 2011.

[67] M. Rashid, M. A. Lone, and S. A. Romshoo, "Geospatial tools for assessing land degradation in Budgam district, Kashmir Himalaya, India," Journal of Earth System Science, vol. 120, no. 3, pp. 423-433, 2011.

[68] S. Zaz and S. A. Romshoo, "Assessing the geoindicators of land degradation in the Kashmir Himalayan Region, India," Natural Hazards, vol. 64, no. 2, pp. 1219-1245, 2012. 

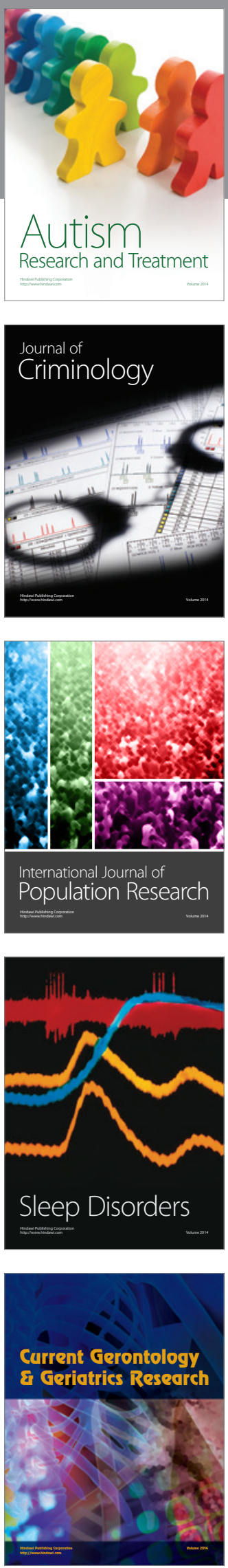
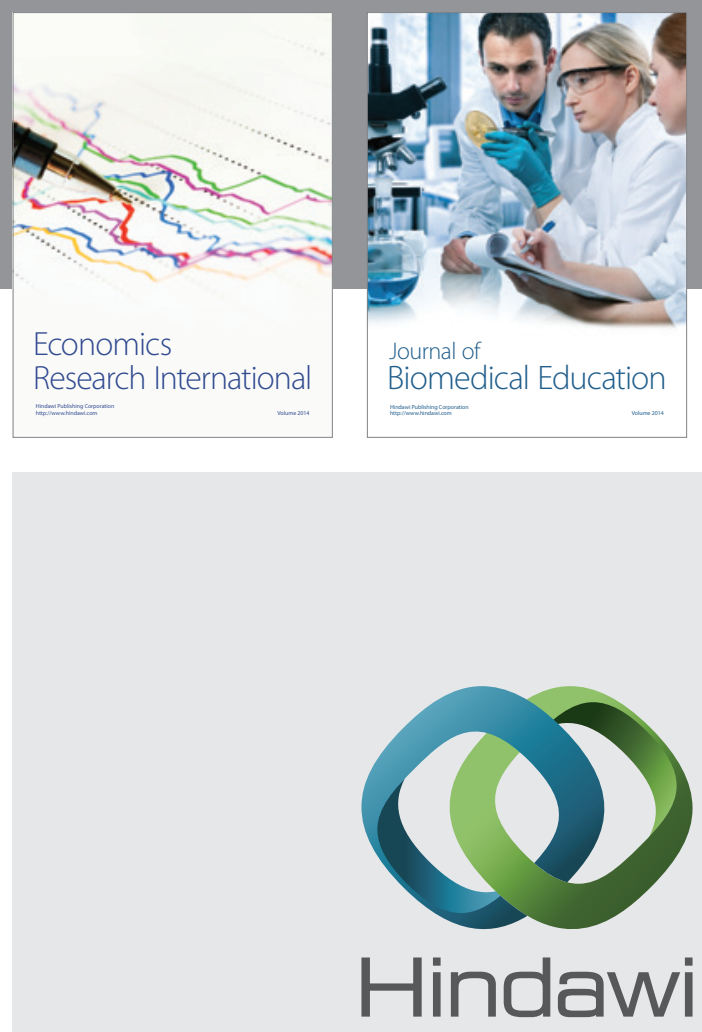

Submit your manuscripts at

http://www.hindawi.com
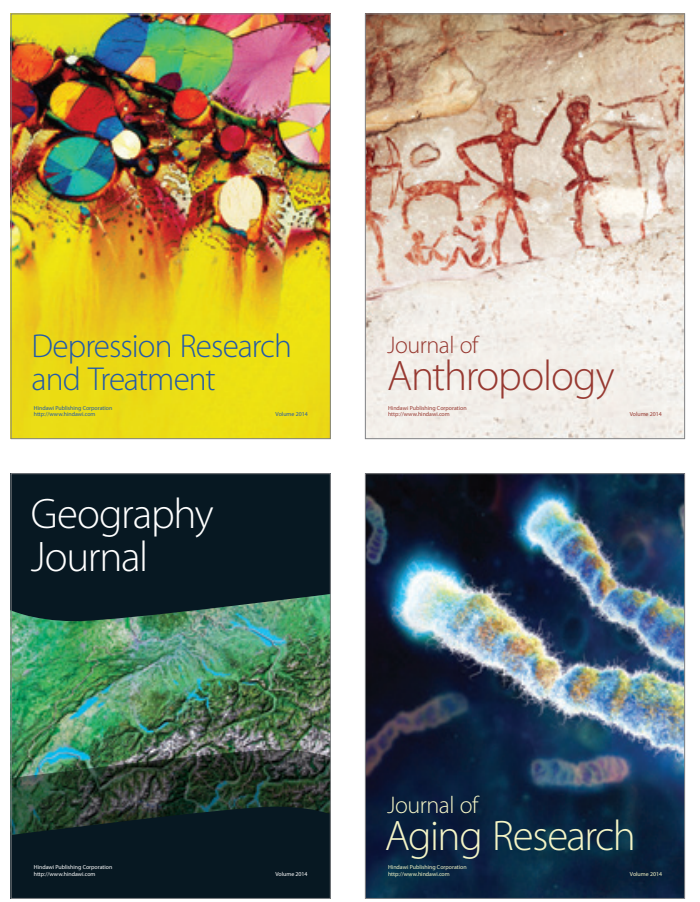
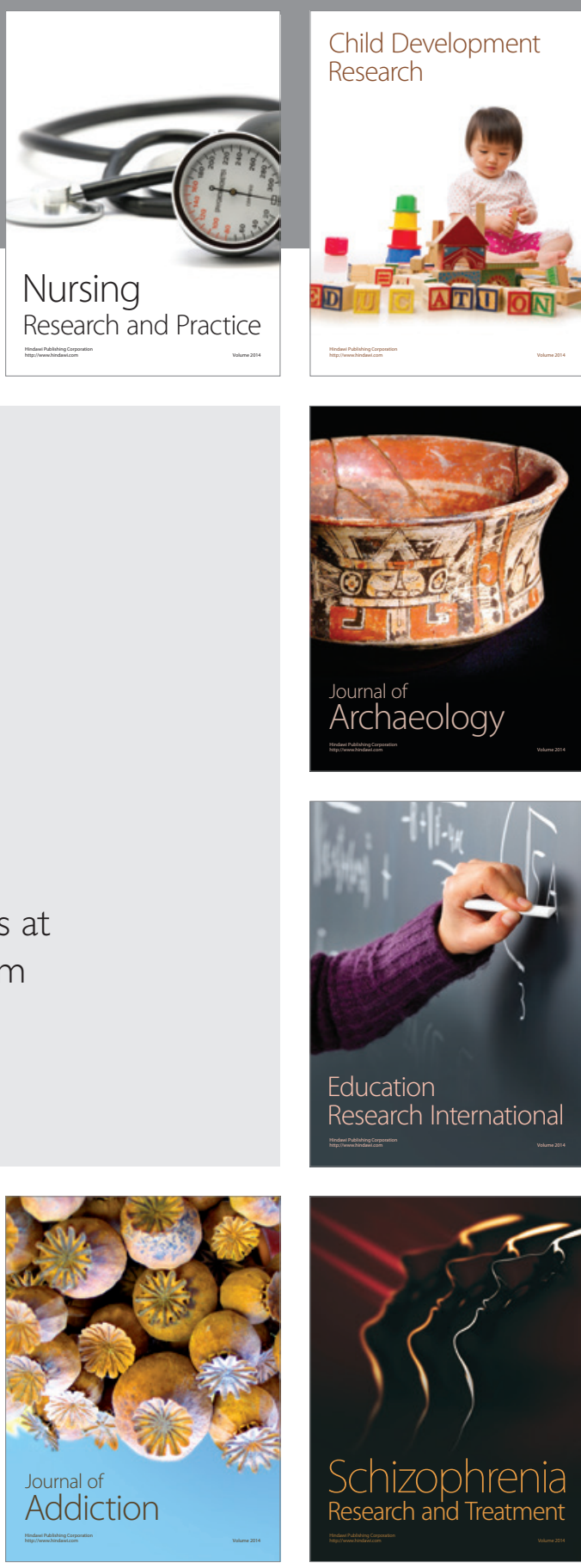

(D)
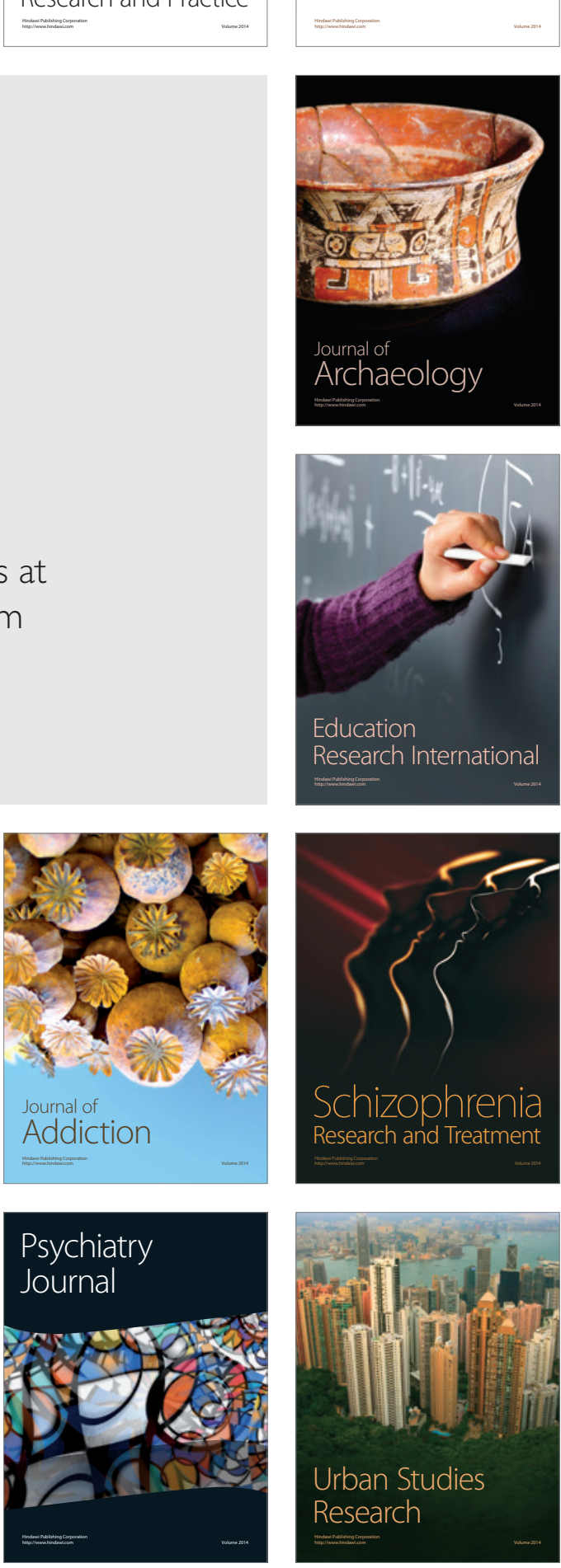